hopes the universities' involvement will help scientists at the weapons laboratories to solve the central technical problem of stockpile stewardship - the full computer simulation of a thermonuclear weapon's operation.

The University of Illinois centre, for example, will study solid-fuel rockets, while Chicago simulates astrophysical thermonuclear flashes. The Utah team will investigate accidental fires and explosions as these impinge on nuclear weapons safety, and Stanford will look at turbulence in gas-turbine engines.

But the Caltech centre will investigate the dynamic response of various materials to the detonation of high explosive - a problem of clear relevance to nuclear weapons design. According to the NRDC draft report, Caltech's proposal included the study of the behaviour of beryllium, uranium and actinide metals under shock from high explosives.

"If the Caltech program is permitted to continue for its five to ten year course, much of the work behind generating a bomb code will have been accomplished," says the NRDC.

Caltech officials now say that these materials will not be included in their study. "We will not be working on nuclear weapons materials, or on anything that is a heavy metal," says Daniel Meiron, head of the Caltech centre. Steve Koonin, provost and vicepresident of research at Caltech, adds that he would "not allow research to be done at Caltech" for the nuclear weapons programme.

The NRDC argues, however, that the shock physics to be carried out at Caltech is exactly what proliferators would require if they wanted to advance from a primitive gun-

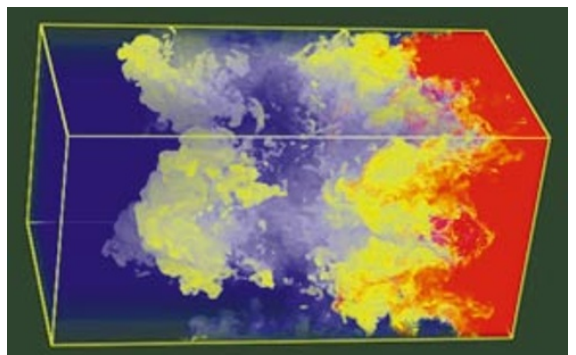

Dual use: simulations of explosions are relevant to both 'shock physics' and weapons design.

type nuclear device to an implosion-based device, or even a hydrogen bomb boosted by a thermonuclear secondary, without testing.

In contrast to the vehement criticism of research related to President Ronald Reagan's Star Wars initiative fifteen years ago, campus reaction to the arrival of money from the nuclear weapons programme has so far been subdued. David Pershing, the head of the Utah centre, says that despite strong antinuclear feeling in the state (which is downwind of the Nevada site where US weapons tests took place), critics have accepted that his team is working on safety, not on building nuclear weapons.

At Caltech, however, the 100-strong Southern California Federation of Scientists has attacked the partnership in local newspapers, and called on David Baltimore, the new president of Caltech, to take a public position on the issue. Baltimore declined to be interviewed for this story, referring questions to Koonin.

The NRDC wants a government review of the proliferation implications of the partner- ships with the universities, and a debate within the universities on whether they should be involved. Its draft report says that the universities' acceptance of the programme "represents an obvious - but financially fortuitous - failure to comprehend the full scope of the current nuclear weapons programme".

The report argues that the \$4.5-billion-ayear stockpile stewardship programme is less concerned with complying with the test ban treaty than with circumventing it, by developing computer models so powerful that the United States will be able to improve its nuclear weapons without testing.

The DOE has consistently denied such charges. But it does accept that the stockpile stewardship programme will help the United States to maintain its nuclear weapons design capability indefinitely, in case new weapons are required in the future, and that part of the function of the partnerships is to help the laboratories recruit scientists for that purpose.

A spokesman for Livermore referred questions about the partnerships to the DOE. But Tom Adams, an ASCI project leader at Los Alamos, says that staff there are enthusiastic about partnerships. "There's a lot of excitement," he says. "People are most anxious to interact with the universities."

Gilbert Weigand, deputy assistant secretary for strategic computing at the DOE, declines to comment on the NRDC's criticisms until its final report is published. But he stresses that the partnerships "are completely unclassified projects", and adds: "They are things the universities wanted to do, in their own best interests."

ColinMacilwain

\title{
Switzerland seeks to head off ban on use of transgenic animals
}

[MUNICH] The Swiss government is trying to pre-empt the outcome of a national referendum calling for major restrictions on genetic engineering - including a ban on the use of transgenic animals - by presenting its own proposals for strengthening the rules governing the use of such techniques.

Known as the 'Gen-Lex' motion, the initiative aims to coordinate existing legislation covering a range of activities relating to genetic engineering, and to close any apparent gaps. Scientists,

environmentalists and animal rights groups have been asked for their comments.

A national ethics committee is also to be set up in the next few months to address issues relating to the use of animals in genetics research. One of its tasks will be to assess whether proposed experiments using transgenic animals are ethically justified.

The referendum, scheduled for June, was initiated in 1992 by pressure groups opposed to biotechnology. Although widely supported by environmentalists and animal rights activists, it has been strongly opposed by many scientists, who warn that its approval would seriously harm biomedical research in Switzerland, and could persuade pharmaceutical companies to relocate elsewhere (see Nature 388, 315; 1997).

"A general ban on the use of transgenic animals would be disastrous for many Swiss researchers," says Franco Cavallo, director of the Institute for Oncology in Bellinzona and a socialist member of the Swiss parliament.

Switzerland has no specific regulations on genetic engineering, as this is considered to be covered by a variety of laws in areas such as environmental and animal protection.

A recent survey has shown that threequarters of the population are opposed to constitutional bans, such as that proposed on the use of transgenic animals. The Gen-Lex motion seeks to build on this aversion to bans by tightening laws designed to ensure that abuses cannot occur.

Although the referendum has firm support from many people, the outcome of the vote is still in doubt. To succeed, it requires the majority of the country's 26 cantons to vote in favour. This is unlikely, according to Cavallo, because there is relatively little opposition to genetic engineering in the French- and Italianspeaking parts of Switzerland.

Cavallo also argues that the Gen-Lex motion is too abstract and complex to persuade supporters of the referendum to change their minds. But Peter Mani, a microbiologist who heads the department of gene technology and society at the University of Zürich, is optimistic that the initiative will help to prevent approval of the measures being put to the referendum by reassuring the public that genetic engineering will be strictly controlled. "The opponents have gone too far in their demands," he says. "Complete bans make the public uneasy."

He believes that, barring a major accident or other event, time and national conservatism are on the scientists' side. "The Swiss are not likely to choose a radical solution unless some unpredicted scientific disaster happens shortly before the referendum," he says. 